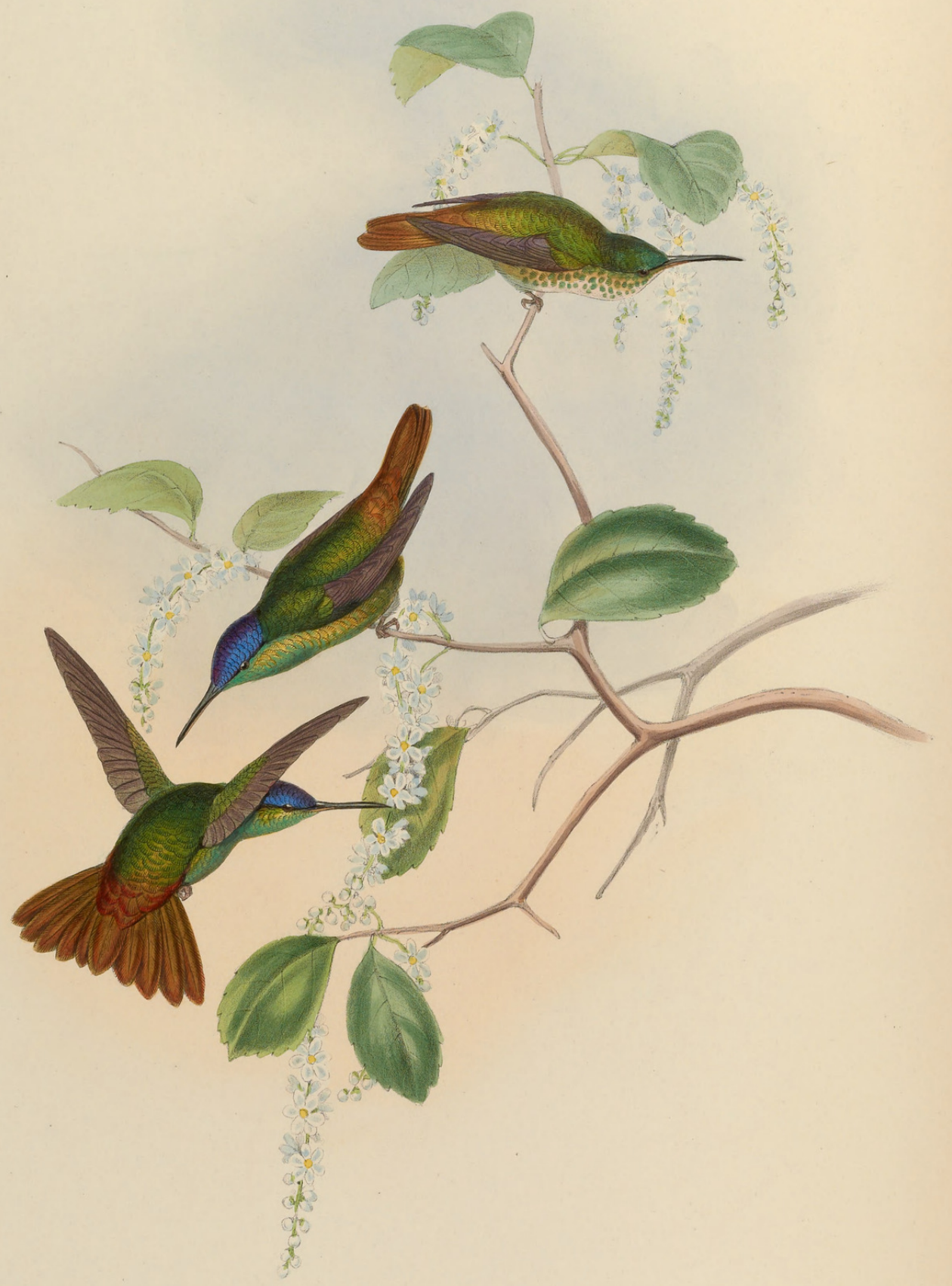




\section{CHRYSURONIA JOSEPHINA. Josephine's Humming-bird.}

Ornismyia Josephince, Bourc. and Muls. Rev. Zool. 1848, p. 272.

Trochilus Josephince, Gray and Mitch. Gen. of Birds, vol. iii. Supp. App. 30A., App. to p. 103.

Chrysuronia Josephina, Reich. Auf. der Col., p. 9.

josephina, Bonap. Rev. Zool. 1854, p. 254.

Josephine's Humming-bird is one of those species with which we are but little acquainted : my own collection contains two examples; one of these I purchased in Paris; the other I received direct from the Upper Amazon, where it was procured by $\mathrm{Mr}$. Bates, a thorough naturalist, endowed with courage, energy, and perseverance fully equal to the performance of the task he has undertaken-that of exploring the rich districts of the Upper Amazon. England may indeed be proud of two such sons as Wallace and Bates, to whom zoologists especially must feel grateful for a vast extension of their scientific knowledge.

In point of affinity this species is very closely allied to the well-known Chrysuronia Enone; like that bird it has a splendid golden-bronzy tail; but the rich blue which adorns the throat as well as the head of that species is confined to the head alone in $C$. Josephine, the whole of whose under surface is green. We really have seen so little of this bird that it is unsafe to say whether the female be or be not contained in our collections; but I may predict that, when discovered, she will be found to differ very little from the female of $\boldsymbol{C}$. Enone.

This species has been dedicated by MM. Bourcier and Mulsant to Madame Julien Lacroix.

Crown of the head rich deep blue, tinged in some specimens with green ; upper surface and wing-coverts golden green ; under surface shining grass-green ; wings purplish brown ; upper tail-coverts coppery bronze ; tail fine golden bronze in some examples, and rich coppery bronze in others; under tail-coverts golden bronze fringed with grey; upper mandible black; under mandible for four-fifths of its length apparently fleshy white, the tip darker.

The figures are of the natural size. 


\section{$2 \mathrm{BHL}$ Biodiversity Heritage Library}

Gould, John. 1861. "Chrysuronia josephinæ, Josephine's Humming-bird. [PI. 326]." A monograph of the Trochilidae, or family of humming-birds 5, https://doi.org/10.5962/p.317135.

View This Item Online: https://www.biodiversitylibrary.org/item/108806

DOI: https://doi.org/10.5962/p.317135

Permalink: https://www.biodiversitylibrary.org/partpdf/317135

\section{Holding Institution}

Smithsonian Libraries

\section{Sponsored by}

Smithsonian Institution Libraries

\section{Copyright \& Reuse}

Copyright Status: NOT_IN_COPYRIGHT

This document was created from content at the Biodiversity Heritage Library, the world's largest open access digital library for biodiversity literature and archives. Visit BHL at https://www.biodiversitylibrary.org. 